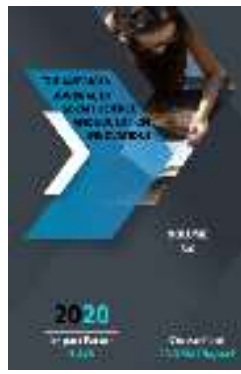

\title{
Methods Of Teaching Speaking Online To Intermediate Level Students
}

\author{
Kholmurodova Gulhayo Nematovna \\ Teacher Of Tashkent State University Of Uzbek Language And Literature, Tashkent City, \\ Uzbekistan
}

\begin{abstract}
Journal Website: http://usajournalshub.c om/index,php/tajssei

Copyright: Original content from this work may be used under the terms of the creative commons attributes 4.0 licence.
\end{abstract}

\section{ABSTRACT}

It is usually easy to reach this level, and progress is always obvious. Students feel their progress and understand that they acquire the language. Usually, when students start with lower levels and feel how fast and easy the progress is made, they feel motivated and interested. At the intermediate level, students may not feel much progress but, in contrast to lower levels, they know enough to express themselves, to initiate and maintain the conversation about serious issues; and they can use language creatively. Also, the class begins to relax a little as students start to communicate more freely without needing so much input and guidance from the teacher. There is a shift of focus from what they don't know (everything, at the lower levels) to what they do know, and what they can do with it. They can deal with most of the basic functions they need and, consequently, many learners never get beyond this level.

\section{KEYWORDS}

Levels, relax, functions, learners, language, issue

\section{INTRODUCTION}

\section{What Is "Teaching Speaking"?}

What is meant by "teaching speaking" is to teach ESL learners to:
- $\quad$ Produce the English speech sounds and sound patterns

- Use word and sentence stress, intonation patterns and the rhythm of the second language. 
- Select appropriate words and sentences according to the proper social setting, audience, situation and subject matter.

- Organize their thoughts in a meaningful and logical sequence.

- $\quad$ Use language as a means of expressing values and judgments.

- Use the language quickly and confidently with few unnatural pauses, which is called as fluency.

\section{How To Teach Speaking}

Now many linguistics and ESL teachers agree on that students learn to speak in the second language by "interacting". Communicative language teaching and collaborative learning serve best for this aim. Communicative language teaching is based on real-life situations that require communication. By using this method in ESL classes, students will have the opportunity of communicating with each other in the target language. In brief, ESL teachers should create a classroom environment where students have real-life communication, authentic activities, and meaningful tasks that promote oral language. This can occur when students collaborate in groups to achieve a goal or to complete a task.

\section{Activities To Promote Speaking}

\section{DISCUSSIONS}

After a content-based lesson, a discussion can be held for various reasons. The students may aim to arrive at a conclusion, share ideas about an event, or find solutions in their discussion groups. Before the discussion, it is essential that the purpose of the discussion activity is set by the teacher. In this way, the discussion points are relevant to this purpose, so that students do not spend their time chatting with each other about irrelevant things. For example, students can become involved in agree/disagree discussions. In this type of discussions, the teacher can form groups of students, preferably 4 or 5 in each group, and provide controversial sentences like "people learn best when they read vs. people learn best when they travel". Then each group works on their topic for a given time period, and presents their opinions to the class. It is essential that the speaking should be equally divided among group members. At the end, the class decides on the winning group who defended the idea in the best way. This activity fosters critical thinking and quick decision making, and students learn how to express and justify themselves in polite ways while disagreeing with the others. For efficient group discussions, it is always better not to form large groups, because quiet students may avoid contributing in large groups. The group members can be either assigned by the teacher or the students may determine it by themselves, but groups should be rearranged in every discussion activity so that students can work with various people and learn to be open to different ideas. Lastly, in class or group discussions, whatever the aim is, the students should always be encouraged to ask questions, paraphrase ideas, express support, check for clarification, and so on.

Using audio-visual materials, textbooks with models, filmstrips, movies and pictorial materials and info graphics or other mind mapping and brain mapping tools in the session that will help learner's imagination thrive and grow. These methods will not only develop their ability to listen, but will also help them understand the concepts better. Another method of teaching is brainstorming. In context to teaching, brainstorming is a 
strategy or tool of teaching used by the teacher in which maximum or all the students participate by responding or presenting views on one topic. This technique encourages new ideas among students which would never have happened under normal circumstances. First, a small group of students is formed. They are asked to sit in a group and are provided with a particular issue or topic. Teacher, as the group leader, then ask group members to think about the problem and give their ideas. They are advised to find as many solutions to the problem as they can find. They are instructed not to criticize others ideas but they are free to make attentions to others ideas. Students are encouraged to put forward suggestions without hesitation even if they seem to come up with unusual and unorthodox ideas. Student's ideas are to be listened and accepted patiently, without passing any judgment or comment of any sort until the session is over. This method encourages the creativity and motivation. One of the methods is classes outside the Classroom. Some lessons are best learnt, when they are taught outside of the classroom. To organize field trips that is relevant to the lessons. The learners will find this fresh and exciting and will learn and remember the things taught faster. Moreover, teaching through role play is a great way to make students step out of their comfort zone and develop their interpersonal skills. Welcoming new ideas an open-minded attitude can help innovating new teaching methods. Though open-minded, sometimes most of us show reluctance to new ideas. Puzzles and Games Learning is fun where puzzles and games are part of education. Puzzles and games help children to think creatively and face challenges. While playing games, the learner's attention is on the message, not on the language. Rather than paying attention to the correctness of linguistic forms, most participants will do all they can to win. The main purpose is to make the learners talk and stimulate their imagination, curiosity and interest. Game of Sudoku, a kind of number puzzle is an ideal authentic context for practicing language functions.

\section{CONCLUSION}

To conclude it should be noted that, the teacher of 21 century should shed traditional concepts and techniques of classroom teaching and should adopt the recent and innovative teaching techniques. English communication skill teachers must be innovative, creative and resourceful with thorough knowledge of the subject and adopt new techniques to change social economic status of our country. Whatever may be the methods and approaches, the most pragmatic and the desirable thing seems to explore the possibility of using the under used and valuable materials which will definitely facilitate the learning and teaching of language skills. We need to have interactive teaching and this changing role of education is inevitable with the introduction of multimedia technology and the spawning of a technologically-savvy generation of youths.

\section{REFERENCES}

1. Kalyani D., Rajasekaran K. Department of Educational Planning and Administration, Tamilnadu Teachers Education University, Karapakkam, Chennai - 600 097, Tamil Nadu, India. Innovative teaching and learning // Journal of Applied and Advanced Research, 2018: 3(Suppl. 1). S. 23-25.

2. Norseha Unina, Polin Bearing. Brainstorming as a Way to Approach Student-Centered Learning in the ESL Classroom. [Electronic Resource]. URL: 
https://www.researchgate.net/publication/ 305394171_Brainstorming_as_a_Way_to_A pp roach_Studentcentered_Learning_in_the_ESL_Classroom / (date of access: 25.11.2019).

3. Sharples M., Adams A., Alozie N., Ferguson R., FitzGerald E., Gaved M. \& Roschelle J., 2015. Innovating Pedagogy 2015: Open University Innovation Report.

4. Baylor A.L. Perceived disorientation and incidental learning in a Web-based environment: Internal and external factors J of Educational Multimedia and Hypermedia Vol. 10/3 227-251:2001.

5. Foglia L. \& Wilson R.A., 2013. Embodied cognition. Wiley Interdisciplinary Reviews: Cognitive Science. 4 (3). 319-325.

6. Patil chetan Vitthal, Bhavna R Sharma, M. Ramachandran. Innovation Practices for Teaching English Communication skills to Professional Students // IJARIIE-ISSN(O)2395-4396. Vol. 1 Issue-2 2015. 